\title{
Review article Getting to the new South Africa from the old
}

Robert Ross

Martin J. Murray, THE REVOLUTION DEFERRED: THE PAINFUL BIRTH OF POST-APARTHEID SOUTH AFRICA, London \& New York: Verso, 1994, pp. xvi $+272 ; £ 39.95$ and $£ 12.95$ (paper).

Crawford Young, THE AFRICAN COLONIAL STATE IN COMPARATIVE PERSPECTIVE, New Haven and London: Yale University Press, 1994, £28.50.

Nigel Worden, THE MAKING OF MODERN SOUTH AFRICA: CONQUEST, SEGREGATION AND APARTHEID, Oxford: Blackwell, 1994, $£ 6.99$

Mike Brogden and Clifford Shearing, POLICING FOR A NEW SOUTH AFRICA, London \& New York: Routledge, $\$ 37.50$ \& $£ 12.99$.

Gavin Cawthra, POLICING SOUTH AFRICA: THE SOUTH AFRICAN POLICE \& THE TRANSITION FROM APARTHEID, London \& New Jersey and Cape Town: Zed Books \& David Philip, $1993, £ 32.95$ and $£ 12.95$ (paper).

John D. Brewer, (ed.), RESTRUCTURING SOUTH AFRICA, London; St. Martin's Press, 1994, £35.00.

Two years after the first inclusive elections in South Africa and the inauguration of Nelson Mandela as the country's President, books which were researched and written on the country before April 1994 may seem to be rather dated. And that, of course, is all of them, as yet. It is not just that the mechanics of book production make anything else impossible. It is also that there has not yet been time for the processes of South African history since then to become clear. It is possible to say what the various actors in the South African political, economic and social processes hope will occur. It is far too soon to say, in anything other than a superficially journalistic way, to make any

Ethnic and Racial Studies Volume 19 Number 2 April 1996

(C) Routledge $1996 \quad 0141-9870$ 
real sense about the degree to which they are going to achieve their ambitions.

What should be done about this? Some years ago a fringe antiapartheid group in The Netherlands tried to throw the contents of the library of the South African Institute into an Amsterdam canal, in the mistaken belief that this would aid the cause of liberation in South Africa. Should we at least figuratively follow their example? Is the library full of books, journals and articles, if not physically to be destroyed, to be left unread on the shelves, as having nothing to say to post-apartheid South Africa? After all, it has been seriously suggested that history be temporarily scrapped from the school syllabus until a form of history which is appropriate to the country as it now is has been developed.

These questions are intended to be ironic. Why this should be so can be seen from the superb book by Crawford Young, even though South Africa scarcely figures in it. Young is a political scientist whose prime focus of research over the years has been Zaire. Not surprisingly, then, his main concern is to explain the collapse of the state, not just in Zaire but also in a wide variety of African countries. This he does on the basis of a history of colonial rule. Put crudely, his argument is that colonial states were authoritarian, anti-democratic and primarily concerned with the extraction of wealth for the benefit of citizens of the mother country. The post-colonial successor states have exhibited the same characteristics, though the beneficiaries of the extraction have changed somewhat and the levels of efficiency, which made colonial societies almost palatable, have declined atrociously.

In itself, Young's work is an intellectual tour de force. The book is as pleasurable as its subject matter is not. Its relevance to South Africa, however, is not in the details of its argument. Whether or not South Africa represented some 'special sort of colonialism', its state structures through the twentieth century have been very different from those further north. Despite notorious racial policies, the exclusion of the blacks from power, and the de facto one party state that existed from 1948 to 1990 , it has, within these limits, always been formally democratic. Elections were held, and at local level were not always irrelevant. Parliament continued to meet, and ministers were responsible to it. These were strengths on which South Africa after 1994 can build. Secondly, Young's stress on the colonial institutional roots of modern African states ignores the possibility that deep-seated ideas of political morality and of virtue within African societies still exercise malign influence over modern politics. In both the stateless societies and the monarchies of East, Central and West Africa, the acquisition of individual wealth, by any means, was widely seen as a prime good. In pre-colonial Southern Africa, significantly largely slave-less, matters were different. The ease with which individuals could abandon their 
rulers, and move to the competitors, or with which political entities could split, provided a degree of structural limitation on royal power which was missing further north. Southern Africa's two greatest modern statesmen, Nelson Mandela and the late Sir Seretse Khama of Botswana, are aristocratic heirs to this tradition, with beneficial results for the countries of which they have been presidents. ${ }^{2}$

The lessons which should be drawn from Young's account for South Africa are thus at a higher level of abstraction. What he makes clear is that, despite the enormous institutional shifts which separate colonial from post-colonial Africa, or South Africa before 1990 from that after 1994, the legacies of earlier states are still to be found in their successors. However attractive, it simply is not feasible, either for analysts or for those actively involved in political life, to act as if this was not the case. History is not superfluous. This has to be the justification for still reading at least some of the many books and articles written about pre-1990 South Africa.

The legacy that was left to post-apartheid South Africa is not universally vicious. If nothing else, opposition to the activities of the state has produced strong and disparate extra-parliamentary monitoring of those very activities, whether from lawyers, churchmen or journalists. Moreover, the apartheid state had to maintain the formalities of the law at least enough to make plausible to those who looked kindly on it that it was a bulwark of Christian civilization against communist barbarity. This, though, is much more than outbalanced by the uncontrolled brutality with which agents of the state attempted to maintain order. These included the army, a whole variety of shadowy, mutually competitive and lethal security bodies and the police.

In these circumstances it is not surprising that there has been a rash of works recently published on the South African police, both to describe and explain its actions under apartheid and to produce ideas about what can be done with the force. The South African police, clearly, was not primarily in the business of catching criminals and preventing crime, at least not as those concepts are defined in most countries in the world. In 1968 the police's official historian noted that only one officer in ten was actually engaged in the detection and investigation of crime, and thereafter the proportion can only have declined. Rather, the police's job was overwhelmingly the maintenance of public order, as defined by the police themselves. The books by Cawthra and by Brogden \& Shearing document what the police have done in detail as chilling as the documentation will allow - not surprisingly, neither book cites interviews with police men and women, nor did the researchers have access to police archives, assuming them to have survived. But what is in the public domain allows the authors to show how the police routinely used torture on all those they hauled in in an attempt to extract information; how large numbers of suspected 
'terrorists' and other opponents of the state met with their deaths in suspicious circumstances while in police custody; and how there is good, if not totally hard, evidence for the existence of police death squads. This was possible because the police built up a subculture in which the officers, a high proportion of whom were of far right-wing sympathies, placed themselves outside the law, in order to achieve the prime purpose of their activities, namely the defeat of communist terrorists' and the maintenance of Christian civilization. This was a counter-productive strategy, as it turned out. Those they considered to be the enemy have now taken power, and the activities of the police did much to undermine the projects to legitimize the apartheid ideology and policies.

Part of the consequence of this line of activity is that the police themselves systematically lost any legitimacy that they may once have had among the vast majority of South Africans. ${ }^{3}$ Both books reviewed here discuss this probably intractable problem. The South African police know the right sort of noises to make, and have been making them. Community participation, democratic control, maximally nonviolent policing, the installation of complaints procedures and so forth have been set as the goals for the police, both internally and by their new political masters. This will all require an enormous shift in police culture, as will the switch in the main emphasis in police work from the maintenance of order to the fight against crime. Odd as it may seem, the police are not usually trained in matters of detection, and their standards of the preservation of physical evidence, for instance, are lamentable. But beyond that, not only will the state have to acquire legitimacy in those areas of South Africa where it never had it - an end for which the cathartic experience of the elections provided a beginning, but which still has to be reached by the daily demonstration of the state's benevolence and power; the police also have to be legitimized in 'the communities'. Brogden and Shearing hope that the extra-statal community structures established during the township revolt of the 1980 s and 1990 s can strike up participation with the police, to provide a two-stream approach by which the poor areas of South Africa can, for the first time, become tolerable and safe. In this, I am not as sanguine. The line between legitimate community structures and protection rackets is a fine one, which has too often been crossed. Brogden and Shearing provide a fine account of the various forms of neo-legal institution which developed to cope with the potential anarchy of situations where the townspeople had rejected any form of government control, whether national or local. They are not convincing that such structure, as they have developed and are developing, are necessarily part of the solution, not part of the problem.

That there is a problem is all too evident. By late 1995 the threat from neo-fascist white extremists to the new order in South Africa has 
receded, probably for good. The fight for political turf between supporters of Buthelezi's Inkatha Freedom Party and those of the African National Congress [ANC] is perhaps not as bloody as at its height, and has largely been localized to Natal, even though a permanent resolution to the conflict has certainly not yet been reached. The South African economy has not collapsed, though it has not grown anything like fast enough to absorb the massive unemployment that has been disfiguring the country for decades. But this has only meant that rates of violent crime, which have long been the highest in the world, have increased. An 'average' South African woman, it has been calculated, can expect to be raped twice in her lifetime! Since the probability of detection is the greatest deterrent to criminal activity, this must be attributed in large measure to the under-policing of South Africa, because historically the police have not been trained or concerned to deal with the murders, assaults and rapes which have disfigured South African society, nor have they had the civilian support which would have enabled them to do so.

Explaining how things grew to be like this is the major concern of historians of South Africa, whose numbers and influence increased sharply during the 1970 s and 1980 s, perhaps because the sort of people who become historians were cut off both from real influence in South African society and from research topics that were too dangerously contemporary. Nigel Worden's short book is a masterful survey of the most important literature on the history of South Africa during the last century, or rather more. It is certainly the best place through which to find what has been written on a whole range of the major topics in the historiography of the country, notably rural change, urbanization, the policies of the state and the changing forms of black resistance. Perhaps it does not itself impose Worden's own vision of the course of South African history on the material, but that is inherent in the format within which he was commissioned to operate.

This format also precludes Worden from dealing with the history of the very recent past of the country. There have been a number of attempts to write the histories of the transition to democratic majority rule, of which Allistair Sparks's Tomorrow is Another Country: the inside story of South Africa's negotiated revolution (London: Heinemann, 1995) is in some ways the best example. Not unnaturally for immediate books written on the very recent past, these are journalistic works (and none the worse for that), concentrating on the activities of the major players in the drama. Martin Murray's The Revolution Deferred, is just about the first attempt to provide a discussion of the wider history of the early 1990 s, one that goes beyond the limitations of political journalism and attempts a more academic analysis. Inevitably, for a work written so fast and so close to the events, it is not a polished work. Murray could have done with a journalist's skill in the 
writing of reasonably stylish prose fast. On the other hand, Murray's long experience of studying opposition politics in South Africa and his knowledge of the less salubrious parts of South African society (which holds the vast majority of the population) allows him to present discussions of recent South African history which are more than the interplay of personalities. He does, of course, present the major groups within the political arena, and shows as clearly as the inevitably sparse evidence permits how vicious political violence disfigured and also drove the process by which a negotiated settlement was achieved, not in general in the ways in which its perpetrators hoped. In addition to this, though, he describes in some detail the role played by organized labour in shaping the way in which South Africans will be able to rebuild their society. Equally importantly, perhaps more so, he can show how those who do not even qualify for the limited privileges of Trade Union membership, and who are forced to live on the margins of society - a mistaken metaphor since in South Africa they are the centre of society - have been unable to create social space for themselves which is not riven by the apolitical violence so prevalent in modern South Africa.

That criminality is so much more a central issue in the debates within South African life than it ever was in the past is, of course, a consequence of changing perspectives on and within the country, not of the daily reality which the mass of South Africans have had to face. The legacy with which post-apartheid South Africa has to deal is grim, and the institutional tools which its rulers have inherited to cope with them are grossly insufficient. In their various ways, the books discussed here all demonstrate this. They cannot present the solutions, because easy recipes are not to be found, and should be distrusted if they are suggested. The history of the past shows how the problems have developed. The history of the future will show how far, in the tortuous and unpredictable ways of political practice, South Africans manage to cope with them.

\section{Notes}

1. This argument is based on John Lonsdale, The moral economy of Mau Mau: wealth, poverty and civic virtue in Kikuyu political thought', in Bruce Berman and John Lonsdale, Unhappy Valley: Conflict in Kenya \& Africa, 2 vols, London, Nairobi \& Athens: James Currey, Heinemann Kenya \& Ohio UP, 1992; T. C. McCaskie, State and Society in Pre-colonial Asante, Cambridge: Cambridge University Press, 1995; and pace, Jan. Vansina, Paths in the Rainforests: Toward a History of Political Tradition in Equatorian Africa, Madison: University of Wisconsin Press, 1990, pp. 239-49.

2. This is not a universal rule. Chief Mangosutho Buthelezi is as aristocratic as Mandela (though not Khama, the hereditary King of the Ngwato) but, perhaps because of the course of Zulu history, not seemingly as imbued with the ideas as to the limitations on a ruler's power.

3. It is not totally ridiculous to suppose that in some areas of the country, including 
444 Robert Ross

some of the roughest, individual policemen were once fairly widely accepted. See Bill Nasson, 'Bobbies to Boers: police, people and social control in Cape Town', in David M. Anderson and David Killingray (eds), Policing the Empire: Government, Authority and Social Control, 1830-1940, Manchester: Manchester University Press, 1991.

ROBERT ROSS is Coordinator of African Studies at Rijks University, Leiden.

ADDRESS: Faculteit der Letteren, Rijks Universiteit, P.N. van Eyckhof 3, Postbus 9515, 2300 RA Leiden, The Netherlands. 